Nigerian Journal of Technology (NIJOTECH)

Vol. 38, No. 1, January 2019, pp. 8 - 14

Copyright@ Faculty of Engineering, University of Nigeria, Nsukka,

Print ISSN: 0331-8443, Electronic ISSN: 2467-8821

www.nijotech.com

http://dx.doi.org/10.4314/njt.v38i1.2

\title{
EFFECTS OF POWDERED GLASS AS AN ADMIXTURE IN CEMENT CONCRETE BLOCK
}

\author{
D. B. Eme ${ }^{1, *}$ and C. Nwaobakata ${ }^{2}$, \\ 1, 2, Department of Civil Engineering, University of Port HarCourt, Rivers State, NIGERIA \\ E-mail addresses: ${ }^{1}$ dennis.eme@uniport.edu.ng, ${ }^{2}$ makus20002000@gmail.com
}

\begin{abstract}
This paper investigated the effects of glass usage in finely divided form on the properties of cement concrete. The powdered glass was used as admixture, replacing cement in the concrete production process. The sourced glass were washed and dried for some days. The dried glass was then crushed into smaller pieces before grinding to finely divided form. Replacement of cement with powdered glass was done at 0-10\% with $2 \%$ increment by weight of cement. Using a design mix of 1:2:4, with a constant water cement ratio of 0.6, the workability of fresh specimens were determined using the slump height procedure. The specimens were then poured in $150 \times 150 \times 150 \mathrm{~mm}$ steel moulds and left for 24 hours. The hardened concrete specimens were cured by complete immersion in water for 7, 14, 21 and 28 days. The result showed that workability increases with increase in admixture content. It further revealed that the compressive strength increases with admixture addition to about $4 \%$ powdered glass addition. The compressive strength at $6 \%$ addition of powdered glass was also higher than that of the conventional concrete. Thus replacement can be done to about $6 \%$ addition of powdered glass by weight of cement. The models developed from the study corroborated well with experimental values as high coefficient of determination values were obtained. The models can thus, be used to predict the compressive strength of powdered glass-cement concrete.
\end{abstract}

Keywords: Admixture, Cement Concrete, Compressive Strength, Slump, Powdered Glass.

\section{INTRODUCTION}

Concrete has proven to be a very important element in the infrastructural development of a nation. The building or development of a nation is a direct consequence of the construction prowess of that nation. Concrete is a composite material, a mixture of cement, aggregates, admixture (if any) and water in the right mix proportion.

The quality of concrete used in any construction go a long way to determining the durability, strength and aesthetics of such construction. The quality of concrete is a direct consequence of the quality of materials used in production and then, the quality of concrete produced is a demonstration of the inherent concrete properties like workability, finishability, consistency, compressive strength etc. [1]

The workability of concrete is often referred to as the ease with which a concrete can be transported, placed and consolidated without excessive bleeding or segregation [2] or the internal work done required to overcome the frictional forces between concrete ingredients for full compaction[3].The compressive strength of concrete is one of the most important property of hardened concrete. The mean compressive strength required at a specific age, usually 28 days, determined the nominal water cement ratio of the mix [3].

The properties of cement concrete can be improved upon or modified through alteration of the elements used in production, bearing in mind, that the economic, safety and aesthetical aspects of the structure are not adversely affected. The improvement of the quality of concrete is greatly encouraged as long as the cost in overall construction procedures is not increased. The amount of waste generated and released into our 
environment is increasing by the day. Most of these wastes are non-biodegradable leading to unpleasant environmental condition and release of hazardous substances. One popular non-biodegradable waste is glass, which is used extensively all over the world in the manufacturing of sheet glass, bottles, glass ware, vacuum tubing, etc. This waste glass if found useful in the construction industry, would go a long way to reducing the pollution threat level of the environment.

There have been different researches on the potential of waste glass usage in the construction industry. Chikhalikar, et al [4] investigated that waste glass due to presence of silica possesses pozzalanic property and when ground to very fine powder can be used to some extent to replace cement and contribute for strength development and durability characteristics. Vasudevan and Kanapathy [5] studied slump property in his research and resulted that compared to control mix, the workability of concrete is much higher, when glass powder is included. Vandhiyan, et al [6] discovered from their study, that the workability was reduced due to the replacement, attributing it to surface area increase and also the angular shape of the glass particles.

Kammarapan [7] presented that there is a systematic increase in the slump as the glass powder in the mix increases. The slump ranged around $40 \mathrm{~mm}$ for the reference mix to $160 \mathrm{~mm}$ at $40 \%$ glass powder replacement. Khtaib, et al [8] studied the performance of glass powder as partial replacement of cement and concluded that the maximum compressive strength occurs at around $10 \%$ glass powder, but beyond $10 \%$, it tends to decrease and is lower than that of the control. Vasudevanand Kanapathy [5] investigated test result at 7, 14 and 28 days of curing of specimens containing waste glass powder as partial replacement of cement and his results showed that, up to $20 \%$ glass powder mix amount shows a positive value of compressive strength at 28 days. Dali and Tande [9] from their study of concrete properties containing waste glass powder, revealed that the compressive strength increment is up to $25 \%$ replacement of cement by waste glass powder but the peak percentage increment is at $20 \%$ replacement.

This study thus, takes a further look into the use of waste glass powder as partial cement replacement in the production process of concrete where durability studies were carried out on the powdered glass cement concrete to investigate the ageing effect of powdered glass on the strength property of cement concrete. This research also went further to developing mathematical models that would aid in predicting cement concrete properties and in determining optimum mix design without experimental procedures.

\section{MATERIALS AND METHODS}

\subsection{Materials}

i. The Dangote brand of cement (R. 425, CB4227) which meets the requirements of [10] obtained from a local shop in Port Harcourt was used for this study.

ii. Granite chippings of maximum size $13 \mathrm{~mm}$ was used as coarse aggregate and sourced from a construction site in University of Port Harcourt.

iii. Fine aggregate used was fine river sand, also sourced from a site in University of Port Harcourt. The sand was sieved to ensure a dirt free sample.

iv. Glass powder was obtained from sourced broken waste assemblage in the University of Port Harcourt Environment. The broken glasses were cleaned, washed and air dried for 3 days. The glasses were then crushed and subjected to sieve analysis with the portion finer than $0.212 \mathrm{~mm}$ then used for the experimental study.

v. Slump cone (Model HM-40, Gilson Company USA) which meets the requirements of [11].

vi. Compressive Strength Machine (Model 4207D, Chandler Eng. USA) which meets the requirements of [12].

vii. Sensitive weighing balance to an accuracy of 0.001g.

viii. $150 \mathrm{~mm} \times 150 \mathrm{~mm} \times 150 \mathrm{~mm}$ steel moulds

ix. Other apparatus were; tag sieves, trowel, curing tank steel rod and electric concrete mixer.

\subsection{Methods}

\subsubsection{Experimental Design}

This research study involved experimental tests and procedures on concrete specimens using powdered waste glass as partial replacement for cement in the production of concrete. The coarse aggregate sizes ranging from $5-13 \mathrm{~mm}$ was used in this study. Fine river sand was used as fine aggregate. Slump tests and Compressive strength tests were conducted on the glass powder- cement concrete at $0 \%, 2 \%, 4 \%$, $6 \% 8 \%$ and $10 \%$ replacement of cement with waste glass powder using a constant mix design of $1: 2: 4$ and water cement ratio of 0.6 


\subsubsection{Concrete Batching, Mixing and Curing}

The batching by weight procedure was employed in this research. The powdered glass replaced the cement by weight composition of $0 \%-10 \%$ of cement with $2 \%$ increment. The 1:2:4 mix design was adopted with a water-cement ratio of 0.6 .For each concrete, two specimens were prepared and the average value of results obtained was used. The concrete cubes produced, were cured for $7,14,21$ and 28 days. The 21 days curing, though not a conventional practice, was included for effective durability analysis using even curing period difference of 7 days.

\subsubsection{Slump Test}

In determination of the workability of concrete, the slump cone procedure was adopted. The slump cone was filled with concrete in three layers with each layer compacted using a steel rod by giving it 25 blows before pouring the next layer. The slump cone was then leveled and allowed for about 120 seconds. The cone was lifted off the concrete, thus allowing the pile of unsupported concrete to collapse

The difference between the initial and the final height of the concrete was then recorded as the slump.

\subsubsection{Compressive Strength Test}

After the slump test, the fresh concrete specimens were poured into cleaned and well oiled concrete cubes and left for 24 hours to set.

The hardened concrete were demoulded off the cubes and cured for 7, 14, 21 and 28 days inside a curing tank by complete immersion in water. The compressive strength of concrete specimens were then determined using the compressive strength machine. The load at which the specimen failed was recorded and compressive strength calculated using Equation (1)

$$
f_{c}=\frac{\text { Maximum Load of Failure }}{\text { Gross sectional Area of cube }}
$$

\subsubsection{Model Development}

The models adopted for this study are approximate second degree polynomials of the form of Equation (2)

$$
f(x)=c_{1}+c_{2} x+c_{3} x^{2}
$$

Where: $f(x)=$ The value of cement concrete property such as slump and $28^{\text {th }}$ day compressive strength $x=$ Percentage powdered glass content $c_{i}=$ Coefficients of property model
Equation (2) would be resolved using the [13] data fitting procedure where $\mathrm{x}$ values are replaced by orthogonal vectors $\{\varnothing\}: \emptyset_{1}=1 ; \emptyset_{2}=x ; \emptyset_{3}=x^{2}$. Thus Equation (2) transform to Equation (3)

$$
f(x)=c_{1} \varnothing_{1}+c_{2} \varnothing_{2}+c_{3} \varnothing_{3}
$$

Resolving Equation (3), we thus have Equation (4) to (6)

$$
\begin{aligned}
& \mathrm{c}_{1} \emptyset_{1}^{T} \emptyset_{1}+\mathrm{c}_{2} \varnothing_{2}^{T} \emptyset_{1}+\mathrm{c}_{3} \varnothing_{3}^{T} \emptyset_{1}=F^{T} \emptyset_{1} \\
& \mathrm{c}_{1} \varnothing_{1}^{T} \emptyset_{2}+\mathrm{c}_{2} \emptyset_{2}^{T} \emptyset_{2}+\mathrm{c}_{3} \varnothing_{3}^{T} \emptyset_{2}=F^{T} \emptyset_{2} \\
& \mathrm{c}_{1} \varnothing_{1}^{T} \emptyset_{3}+\mathrm{c}_{2} \varnothing_{2}^{T} \emptyset_{3}+\mathrm{c}_{3} \varnothing_{3}^{T} \emptyset_{3}=F^{T} \emptyset_{3}
\end{aligned}
$$

Where: $\left\{\varnothing_{1}^{T}, \emptyset_{2}^{T}, \emptyset_{3}^{T}\right\}$ are transpose of orthogonal vectors; $\left\{\varnothing_{1}, \emptyset_{2}, \emptyset_{3}\right\}$ respectively.

\section{RESULTS AND DISCUSSIONS}

\subsection{Slump}

The result of slump (workability) tests for the powdered glass-cement concrete is as presented in Figure 1.

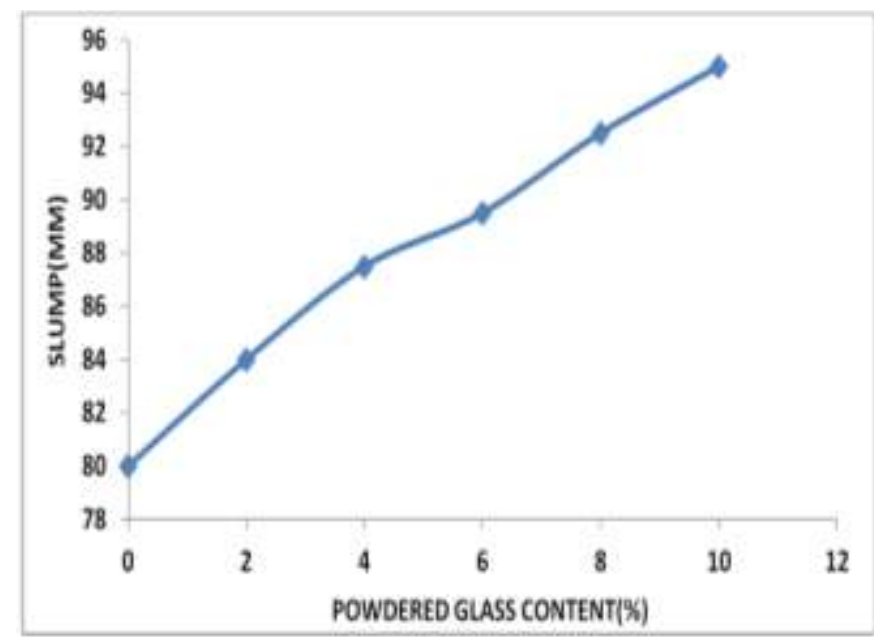

Figure 1: Variation of Mean Slump values with PG content

The workability of powdered glass cement concrete increases as the powdered glass content increases (Figure 1). There is a systematic increase from $80 \mathrm{~mm}$ (for control mix) to $95 \mathrm{~mm}$ (at $10 \%$ replacement). This is in line with the study of [7] who noticed a systematic increase in the slump values of cement concrete with powdered glass addition attributing the increment to the difference in densities of glass powder and cement.

\subsubsection{Compressive Strength}

The $7^{\text {th }}, 14^{\text {th }}, 21^{\text {st }}$ and $28^{\text {th }}$ day compressive strength test result for the powdered glass cement concrete is presented as shown in Figure 2. 
The results from compressive strength tests showed that the compressive strength of powdered glass cement concrete increases with increase in concentration of powdered glass (Figure 2) to $4 \%$ powdered glass by weight of cement content. Above $4 \%$ replacement, the compressive strength tends to reduce but as shown in Figure 2, the compressive strength at $6 \%$ replacement is higher than that of the control mix, thus, replacement can be done up to $6 \%$ powdered glass by weight of cement. At $6 \%$ replacement of cement with powdered glass, an average compressive strength value of $21.25 \mathrm{~N} / \mathrm{mm}^{2}$ which is a C20 grade concrete recommended as the minimum concrete grade for plain concrete construction [14].

\subsubsection{Effect of Ageing on Compressive Strength of Glass-Cement Concrete}

The effect of powdered glass on compressive strength of cement as it ages is presented in Figure 3 where the strength increment is plotted against age of concrete.

From the ageing effect analysis, the strength increment increases systematically with the age of concrete (Figure 3). As the concrete ages, more strength is gained relative to the control specimen. As shown in Figure 3, the percentage increment rose from $2.26 \%$ (at 7 days) to $12.84 \%$ (at 28 days) for $2 \%$ replacement. For the optimum percentage replacement (4\%), there is a systematic increase from $12.43 \%$ to $23.47 \%$. At $6 \%$ replacement, the strength increment was irregular, decreasing from $10.51 \%$ to $1.53 \%$ (from 7 to 14 days), increasing from $1.53 \%$ to $9.14 \%$ (from 14 to 21 days) and then decreased again from $9.14 \%$ to $3.91 \%$ (from 21 to 28 days). This depicts that the powdered glass can be safely relied upon in replacing cement for concrete production without detrimental long term effect on concrete compressive strength within the confines of the optimal replacement of cement with powdered glass.

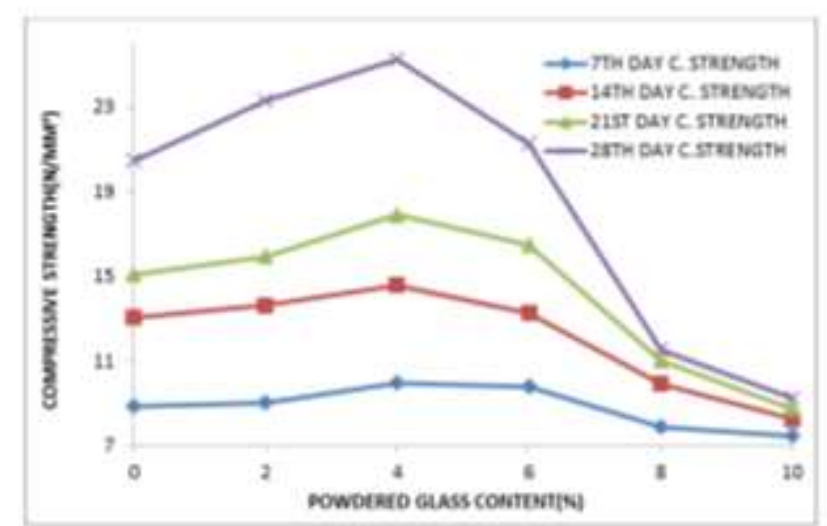

Figure 2: Variation of Compressive Strength with PG content

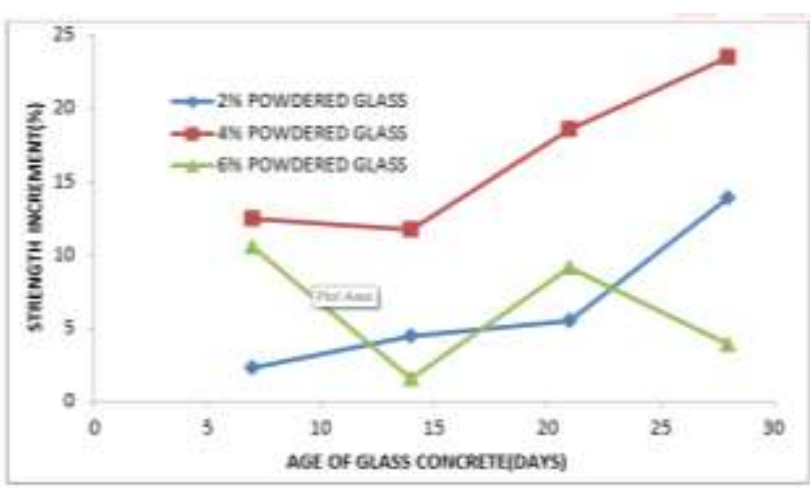

Figure 3: Compressive Strength Increment of Ageing Glass Concrete

\subsection{Modeling the Properties of Powdered Glass Cement Concrete}

Models developed here, are of the form of Equation (2) obtained by resolving Equations (4) to (6).

\subsubsection{Slump/Workability Model}

Table 1 gives a representation of slump values and orthogonal vectors used in the determination of coefficients of slump model.

Table 1: Values for determining coefficients of Slump Model

\begin{tabular}{ccccccc}
\hline$\emptyset_{1}$ & 1 & 1 & 1 & 1 & 1 & 1 \\
\hline$x_{1}=\emptyset_{2}$ & 0 & 2 & 4 & 6 & 8 & 10 \\
$x^{2}=\emptyset_{3}$ & 0 & 4 & 16 & 36 & 64 & 100 \\
$F(x)$ & 80.00 & 84.00 & 87.50 & 89.50 & 92.50 & 95.00 \\
\hline
\end{tabular}

Substituting values into Equations (4) to (6), Equations (7) to (9) are produced 


$$
\begin{aligned}
& C_{1}[111 . .1]\left[\begin{array}{l}
1 \\
1 \\
1 \\
1 \\
1 \\
1
\end{array}\right]+C_{2}\left[\begin{array}{l}
0,2,4, \ldots .10
\end{array}\right]\left[\begin{array}{l}
1 \\
1 \\
1 \\
1 \\
1 \\
1
\end{array}\right]+C_{3}\left[\begin{array}{llll}
0 & 4 \ldots 100
\end{array}\right]\left[\begin{array}{l}
1 \\
1 \\
1 \\
1 \\
1 \\
1
\end{array}\right]=\left[\begin{array}{llll}
80 & 84 & \ldots & 95
\end{array}\right]\left[\begin{array}{l}
1 \\
1 \\
1 \\
1 \\
1 \\
1
\end{array}\right] \\
& \left.\mathrm{C}_{1}[111 . .1]\left[\begin{array}{c}
0 \\
2 \\
4 \\
6 \\
8 \\
10
\end{array}\right]+\mathrm{C}_{2}[0,2,4, \ldots 10]\left[\begin{array}{c}
0 \\
2 \\
4 \\
6 \\
8 \\
10
\end{array}\right]+\mathrm{C}_{3}\left[\begin{array}{lll}
0 & 4
\end{array}\right] .100\right]\left[\begin{array}{c}
0 \\
2 \\
4 \\
6 \\
8 \\
10
\end{array}\right]=\left[\begin{array}{lll}
80 & 84 . .95
\end{array}\right]\left[\begin{array}{c}
0 \\
2 \\
4 \\
6 \\
8 \\
10
\end{array}\right]
\end{aligned}
$$

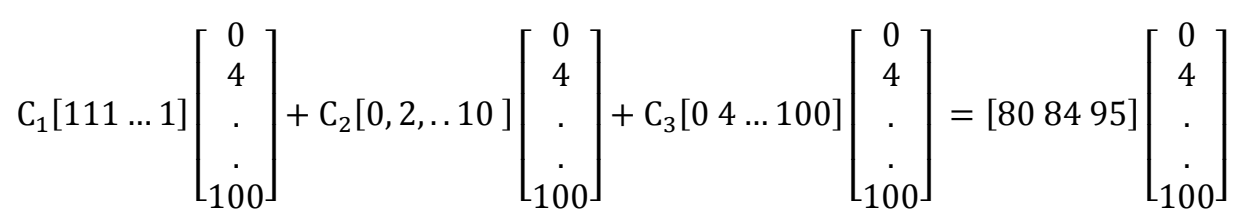

Simplifying further, Equation (7) to (9) becomes;

$$
\begin{gathered}
6 \mathrm{C}_{1}+30 \mathrm{C}_{2}+220 \mathrm{C}_{3}=528.50 \\
30 \mathrm{C}_{1}+220 \mathrm{C}_{2}+1800 \mathrm{C}_{3}=2745 \\
220 \mathrm{C}_{1}+1800 \mathrm{C}_{2}+15664 \mathrm{C}_{3}=20378
\end{gathered}
$$

Solving Simultaneously;

$$
\mathrm{C}_{1}=80.20 ; \mathrm{C}_{2}=1.89 ; \mathrm{C}_{3}=-0.04
$$

Model for predicting the slump of powdered glass cement concrete becomes, as represented by Equation (10):

$$
\mathrm{F}(x)_{\mathrm{m}}=80.20+1.89 x-0.04 x^{2}
$$

\subsection{2 $28^{\text {th }}$ Day Compressive Strength Model} Table 2 gives a representation of $28^{\text {th }}$ day compressive strength values and orthogonal vectors used in the determination of coefficients of $28^{\text {th }}$ day compressive strength model.

Table 2: Values for determining coefficients of $28^{\text {th }}$ Day Compressive Strength Model

\begin{tabular}{ccccccc}
\hline$\emptyset_{1}$ & 1 & 1 & 1 & 1 & 1 & 1 \\
\hline$x=\emptyset_{2}$ & 0 & 2 & 4 & 6 & 8 & 10 \\
$x^{2}=\emptyset_{3}$ & 0 & 4 & 16 & 36 & 64 & 100 \\
$F(x)$ & 20.45 & 23.28 & 25.25 & 21.25 & 11.25 & 9.23 \\
\hline
\end{tabular}

Substituting values into Equation (4) to (6), Equation (11) to (13) is developed

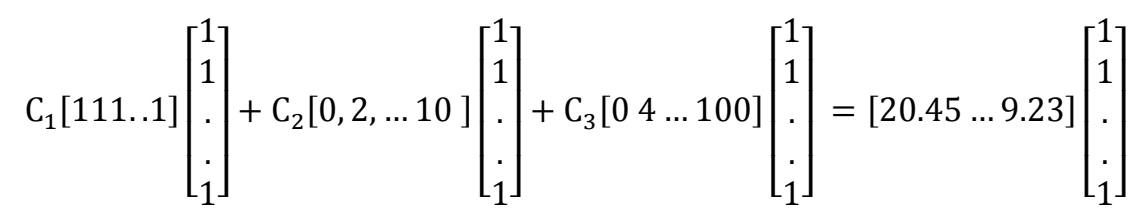

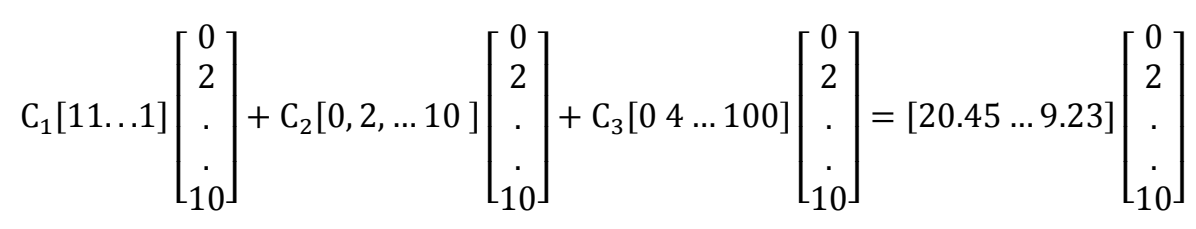

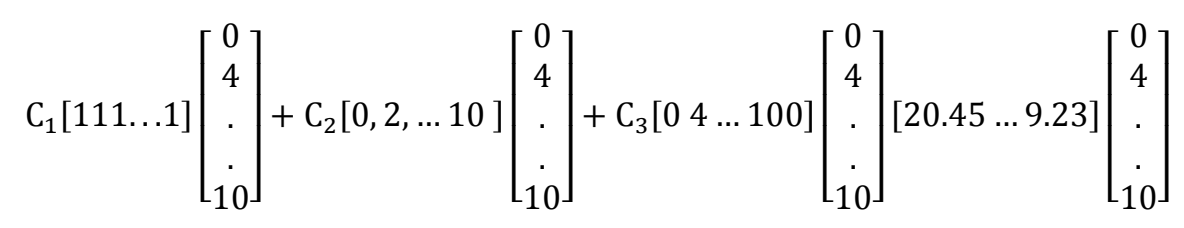


Which upon simplification, becomes

$$
\begin{gathered}
6 \mathrm{C}_{1}+30 \mathrm{C}_{2}+220 \mathrm{C}_{3}=110.99 \\
30 \mathrm{C}_{1}+220 \mathrm{C}_{2}+1800 \mathrm{C}_{3}=459.60 \\
220 \mathrm{C}_{1}+1800 \mathrm{C}_{2}+15664 \mathrm{C}_{3}=2923.04
\end{gathered}
$$

Solving Simultaneously,

$$
\mathrm{C}_{1}=20.999 ; \mathrm{C}_{2}=1.870 ; \mathrm{C}_{3}=-0.323
$$

Model for predicting the $28^{\text {th }}$ day compressive strength of powdered glass cement concrete becomes as represented by Equation (14);

$$
\mathrm{F}(x)_{\mathrm{c}}=20.999+1.87 x-0.323 x^{2}
$$

\subsection{Comparison of Powdered Glass Cement Concrete Properties Values'}

Table 3 presents the predicted powdered glass cement concrete properties values and the average experimental powdered glass cement concrete property values.

The model properties values' are very close to the experimental values' as can be depicted from Table 3. From the experimental procedures, the optimum replacement of cement with powdered glass is between $4 \%$ and $6 \%$ whereas from the model values, the optimum replacement is between $2 \%$ and $4 \%$. For the $6 \%$ replacement, the $28^{\text {th }}$ day compressive strength was recorded as $21.25 \mathrm{~N} / \mathrm{mm}^{2}$ and $20.59 \mathrm{~N} / \mathrm{mm}^{2}$ for the experimental and model values respectively indicating a C20 grade concrete sufficient for plain concrete works [14].

\subsection{Optimum Powdered Glass Content from Developed Models}

Figure 4 shows the plot of the variation of predicted $28^{\text {th }}$ day compressive strength values with powdered glass percentage content

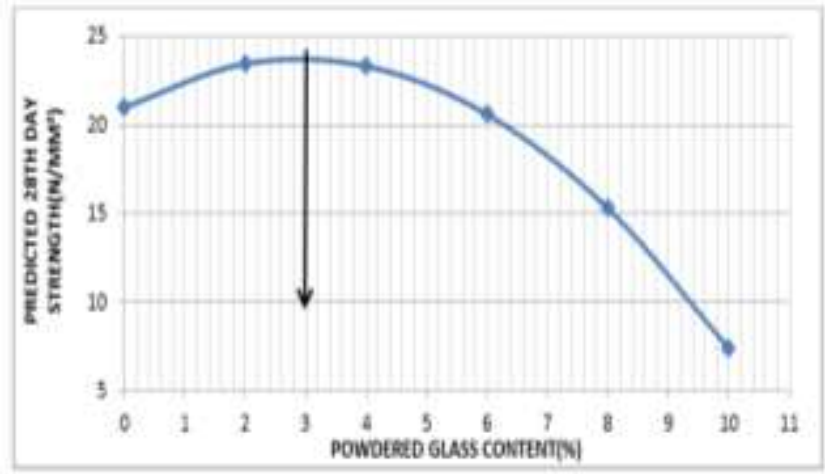

Figure 4: Variation of Predicted $28^{\text {th }}$ day strength with PG content

From Figure 4, although the optimum replacement of cement with powdered glass is 3\% which is lower than the $4 \%$ obtained from the experimental procedures, the partial replacement can also be done to $6 \%$ powdered glass content as the strength value obtained at this replacement is approximately equal to that of the control.

\subsection{Validation of Models}

The models developed in this study were subjected to the R-square statistical procedure for validation. The $R^{2}$ values were determined according to Equation (15).

Where;

$$
R^{2}=\frac{\Sigma(\text { yest }-\bar{y})^{2}}{\Sigma(y-\bar{y})^{2}}
$$

$\mathrm{y}_{\text {est }}$ is the Predicted value of concrete property $y$ is the Experimental value of concrete property

$\bar{y}$ is the Average experimental property value Using Equation (13), $\mathrm{R}^{2}$ values of 0.97 and 0.90 were obtained for slump and $28^{\text {th }}$ day compressive strength models respectively.

Table 3: Experimental Properties Values' and Model Properties Values'

\begin{tabular}{ccccc}
\hline $\begin{array}{l}\text { Powdered glass content } \\
(\%)\end{array}$ & \multicolumn{2}{c}{ Slump $(\mathrm{mm})$} & \multicolumn{2}{c}{$28^{\text {th }}$ day strength $\left(\mathrm{N} / \mathrm{mm}^{2}\right)$} \\
\cline { 2 - 4 } & $\begin{array}{c}\text { Average experiment } \\
\text { value }\end{array}$ & $\begin{array}{c}\text { Model } \\
\text { value }\end{array}$ & $\begin{array}{c}\text { Average experiment } \\
\text { value }\end{array}$ & $\begin{array}{c}\text { Model } \\
\text { value }\end{array}$ \\
\hline 0 & 80.00 & 80.20 & 20.45 & 20.999 \\
2 & 84.00 & 83.82 & 23.28 & 23.447 \\
4 & 87.50 & 87.12 & 25.25 & 23.311 \\
6 & 89.50 & 90.10 & 21.25 & 20.591 \\
8 & 92.50 & 92.76 & 11.53 & 15.287 \\
10 & 95.00 & 95.10 & 9.23 & 7.399 \\
\hline
\end{tabular}




\section{CONCLUSIONS}

After the study on the effect of partial replacement of cement with powdered glass, the following conclusions have been drawn;

1. The workability of powdered glass cement concrete increases with increase in powdered glass concentration.

2. Although the optimum replacement of cement with powdered glass is $4 \%$, replacement can be done up to $6 \%$ as the compressive strength obtained is higher compared to that of the conventional concrete

3. The powdered glass cement concrete produce durable cement concrete product within the optimum replacement bracket as deduced from the ageing effect analysis.

4. The optimum value of $4 \%$ was deduced for all curing periods adopted for analysis.

5. The slump and $28^{\text {th }}$ day compressive strength models deduced from this study can be used adequately in predicting the workability and strength of glass cement concrete as they corroborated well with experimental values depicted by the high $\mathrm{R}^{2}$ values.

\section{REFERENCES}

[1] Ochepo, J. and Salahudeen, A. B. "Durability Of Cement Concrete Partially Replaced With Baggase Ash Subjected To Aggressive Environments". Books of Proceedings, International Conference for Sustainable Development (ICSD) in Africa in The $21^{\text {st }}$ Century. Post Graduate School, Ladoke Akintola University of Technology, Ogbomosho, Nigeria, 2015.

[2] Rajput R. K. Engineering Material (including construction Materials). New Delhi .S. Chand \& Co. Ltd. 2006.

[3] Online (2017). Composition of Glass. www.cmog.org/article/chemistry of glass. Retrieved 10th August, 2017.

[4] Chikhalikar, S. M. and Tande, S. N. "An Experimental Investigation on Characteristics Properties of Fibre Reinforced Concrete Containing Waste Glass Powder as
Pozzolana". $37^{\text {th }}$ Conference on our World in Concrete and Structures Singapore, August. 2012.

[5] Vasudevan, G. and Kanapathy, P. "Performance of Using Waste Glass Powder in Concrete as Replacement of Cement". American Journal of Engineering Research. Vol. 2., issue 12. 2013.

[6] Vandhiyan, R., Ramkuma, K. and Ramya, R. "Experimental study on replacement of cement by glass powder" international Journal of Technology (IJERT). Vol. 2, Issue 10. ISSN 2278-0181. 2013.

[7] Kamarappan, N. "Partial Replacement of Cement in Concrete Using Waste Glass". International Journal of Engineering Research and Technology (IJERT). Vol. 2, Issue 10 ISSN; 2278-0181. 2013.

[8] Khatib, J. M., Sohl, H. S. and Chileshe, N. "Glass Powder Utilization in Concrete Production". European Journal of Applied Science. 4(4). Pp173-176. 2012.

[9] Dali, J. S. and Tande, S. N. "Performance of Concrete Containing Mineral Admixtures Subjected to High Temperature"; $37^{\text {th }}$ Conference on Our World in Concrete and Structure, Singapore, August. 2012.

[10] British Standard Institution. Standard Specification for Portland Cement. British standard, BS 12. 1996.

[11] British Standard Institution Standard Specification for Determination of Slump (BS 1881. Part 102). London British Standard Institution. 1983.

[12] British Standard Institution Standard Specification for Determination of Compressive Strength (BS. 1881. Part 115). London, British Standard Institution.

[13] Oko C.O.C.. Engineering Computational Methods; An Algorithm. First Edn. University of Port Harcourt, Press, Port Harcourt, Nigeria pp. 5022008.

[14] Mosley B., Bungey J., and Hulse R. Reinforce Concrete Design to Eurocode 2. Sixth Edition, Palgrave Macmillian, pp12. 2007. 